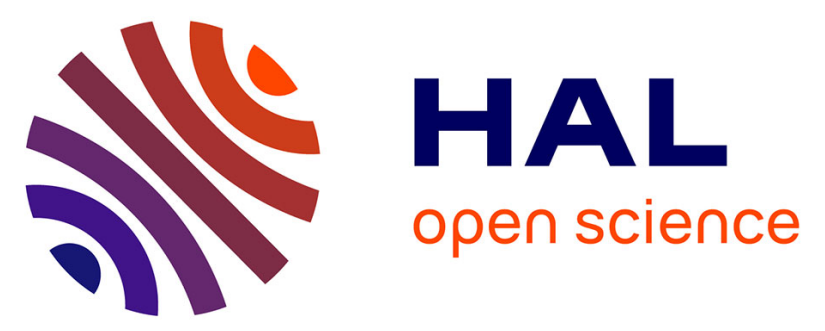

\title{
The PRECOS framework: Measuring the impacts of the global changes on soils, water, agriculture on territories to better anticipate the future
}

Fabienne Trolard, Guilhem Bourrié, Antoine Baillieux, Samuel Buis, André Chanzy, Philippe Clastre, Jean-François Closet, Dominique Courault, Marie-Lorraine Dangeard, Nicola Di Virgilio, et al.

\section{To cite this version:}

Fabienne Trolard, Guilhem Bourrié, Antoine Baillieux, Samuel Buis, André Chanzy, et al.. The PRECOS framework: Measuring the impacts of the global changes on soils, water, agriculture on territories to better anticipate the future. Journal of Environmental Management, 2016, 181, pp.590601. 10.1016/j.jenvman.2016.07.002 . hal-03353088

\section{HAL Id: hal-03353088 \\ https://hal.science/hal-03353088}

Submitted on 24 Sep 2021

HAL is a multi-disciplinary open access archive for the deposit and dissemination of scientific research documents, whether they are published or not. The documents may come from teaching and research institutions in France or abroad, or from public or private research centers.
L'archive ouverte pluridisciplinaire HAL, est destinée au dépôt et à la diffusion de documents scientifiques de niveau recherche, publiés ou non, émanant des établissements d'enseignement et de recherche français ou étrangers, des laboratoires publics ou privés.

\section{(이) $\$$}

Distributed under a Creative Commons Attribution - NonCommercial - NoDerivatives 44.0 


\title{
The PRECOS framework: Measuring the impacts of the global changes on soils, water, agriculture on territories to better anticipate the future
}

\author{
Fabienne Trolard ${ }^{\mathrm{a}, *}$, Guilhem Bourrié ${ }^{\mathrm{a}}$, Antoine Baillieux ${ }^{\mathrm{b}}$, Samuel Buis ${ }^{\mathrm{a}}$, André Chanzy ${ }^{\mathrm{a}}$, \\ Philippe Clastre ${ }^{\mathrm{a}}$, Jean-François Closet $^{\mathrm{c}}$, Dominique Courault ${ }^{\mathrm{a}}$, Marie-Lorraine Dangeard ${ }^{\mathrm{a}}$, \\ Nicola Di Virgilio ${ }^{\mathrm{d}}$, Philippe Dussouilliez ${ }^{\mathrm{e}}$, Jules Fleury ${ }^{\mathrm{e}}$, Jérémy Gasc ${ }^{\mathrm{f}}$, Ghislain Géniaux ${ }^{\mathrm{g}}$, \\ Rachel Jouan ${ }^{\mathrm{f}}$, Catherine Keller ${ }^{\mathrm{e}}$, Patrice Lecharpentier ${ }^{\mathrm{a}}$, Jean Lecroart ${ }^{\mathrm{f}}$, Claude Napoleone ${ }^{\mathrm{g}}$, \\ Gihan Mohammed ${ }^{\mathrm{a}}$, Albert Olioso ${ }^{\mathrm{a}}$, Suzanne Reynders ${ }^{\mathrm{h}}$, Federica Rossi ${ }^{\mathrm{d}}$, Mike Tennant ${ }^{\mathrm{i}}$, \\ Javier de Vicente Lopezj
}

${ }^{a}$ INRA, UAPV, UMR Mediterranean Environment and Modelling of Agro-Hydrosystems, Domaine Saint-Paul, Site Agroparc, 222 Route de l'Aérodrome, 84914 Avignon cedex 9, France

*e-mail : trolard@avignon.inra.fr

${ }^{\mathrm{b}} \mathrm{SYMCRAU}$, Istres, France

${ }^{\mathrm{C}} \mathrm{G} 2 \mathrm{C}$ Ingénierie, groupe Altereo, Venelles, France

${ }^{\mathrm{d}}$ CNR, IBIMET, Institute of Bioclimatology, Bologna, Italy

eAix-Marseille University, CNRS, IRD, Collège de France, UM34 CEREGE, Aix-en-Provence, France

${ }^{\mathrm{f}}$ ARTELIA, Paris, France

${ }^{g}$ INRA, UR Ecodevelopment, Avignon, France

${ }^{\mathrm{h}}$ INRA, DIV and DS Environment, Sophia Antipolis, France

${ }^{\mathrm{i}}$ Imperial College, Center for Environmental Policy, London, UK

${ }^{\mathrm{j}}$ VAERSA, Valencia, Spain

\begin{abstract}
In a context of increased land and natural resources scarcity, the possibilities for local authorities and stakeholders of anticipating evolutions or testing the impact of envisaged developments through scenario simulation are new challenges.

PRECOS's approach integrates data pertaining to the fields of water and soil resources, agronomy, urbanization, land use and infrastructure etc. It is complemented by a socio-economic and regulatory analysis of the territory illustrating its constraints and stakes. A modular architecture articulates modeling software and spatial and temporal representations tools. It produces indicators in three core domains: soil degradation, water and soil resources and agricultural production.

As a territory representative of numerous situations of the Mediterranean Basin (urban pressures, overconsumption of spaces, degradation of the milieus), a demonstration in the Crau's area (Southeast of France) has allowed to validate a prototype of the approach and to test its feasibility in a real life situation. Results on the Crau area have shown that, since the beginning of the $16^{\text {th }}$ century, irrigated grasslands are the cornerstones of the anthropic-system, illustrating how successfully men's multi-secular efforts have maintained a balance between environment and local development. But today the ecosystem services are jeopardized firstly by urban sprawl and secondly by climate change. Pre-diagnosis in regions of Emilia-Romagna (Italy) and Valencia (Spain) show that local end-users and policy-makers are interested by this approach. The modularity of indicator calculations and the availability of geo-databases indicate that PRECOS may be up scaled in other socioeconomic contexts.
\end{abstract}

Key words: soil, water, resources, territory, urban sprawl, climate change.

Published in Journal of Environmental Management, July 2016,

doi:10.1016/j.jenvman.2016.07.002 


\section{Introduction}

Present crisis and transitions all have in common that they concern primary production fields (agriculture, raw materials), transformation activities (industry and crafts) and local economy (retail, general services and transport...) (Pachauri and Reisinger, 2007; IEA, 2008). They impact land use and resources (water, food and energy) and they are mutually interdependent. Thus the gradual awareness of the "crisis" dimension leads to a renewed approach of resources and regional areas' management systems (World Bank, 2007, 2009; FAO, 2009; Trolard and Dangeard, 2014). To face these challenges, efforts should focus on:

- Capacity building in relationship to territorial analysis at different organizational levels. Systemic analysis, life-cycle analysis (Day, 1981; Ayres, 1995; Ayres et al., 1998; von Bahr and Steen, 2004) and integrative concepts (biophysical, biological indicators, ecological footprint, virtual water...) (Bell and Morse, 2004; Graymore et al., 2008) already are a dominant trend of recent literature (Bouman et al., 1999; Crescenzi et al., 2007; Davodi, 2012);

- $\quad$ Reinforcing expertise provision in different but complementary disciplines, such as support for the shaping and monitoring of public policies, critical assessment and dissemination of references or devising innovations with attention to their social acceptability;

- Merging and/or adapting technological innovations from other sectors in order to develop new analysis or expertise tools for territorial development (e.g. energy network models to assess cumulative environmental impact of urbanization on carbon emission (Chen and Chen, 2012) or on river ecosystems (Chen et al., 2015)). Recent innovation in spatial metrology both in the fields of robotics and of information technologies and communication, now makes it possible to propose new management practices, assessment, monitoring and decision support tools (Xia Li and Gar-On Yeh, 2000; Waddel, 2002; Vohland and Barry, 2009...).

Cities, as they develop, have a tendency to degrade environmental assets, and impair the essential services provided by ecosystems. The difficulty resides in the evaluation of benefits provided by natural and agricultural areas. The changes thus introduced by urban development in the agro- and ecosystems increase the risks and retroactively impact the value of constructible land and of property because of regulation constraints (extension of nonconstructible surfaces) and/or conditions attached to the safeguarding of investments (insurance, cost of loans....).

Cities are drivers for innovation (Glaeser, 2011) and urban growth is a productivity factor, enabling producers from rural areas, consumers and companies to access markets and the workforce to find employment. Hence, a first series of studies undertaken by ECOLOC (Club Sahel and OECD, 2001) has established that the concept of local economy ought to coincide with a tangible reality, for instance that of a pilot economic zone-- always open towards other 
areas, regions, countries, world -- but populated enough and with activities that are sufficient for having the potential for generating value and commercial exchanges.

Urbanization develops mainly at the expense of agricultural land at the outskirts of cities (Chakir and Madignier, 2006; Ruellan, 2010; Sapoval, 2011) and along coastal areas (Pageaud and Carré, 2009). For the moment, assessing the consequences of urban sprawl basically boils down to measuring surfaces consumed; it does not take into account the qualitative properties associated to soils and associated environmental functions before sealing.

To overcome such contradictions, it is necessary to identify the impacts of urban and agricultural policies over natural environments, to assess externalities and anticipate evolutions.

The PRECOS framework allows for simulating the likely evolution of indicators in the future and, in the light of various constraints, assessing the deterioration risks of local environmental assets and the lessening of decision makers' means and levers for potential action.

The main goal of this paper is to present the different elements of this approach highlighted by results obtained on the demonstration area, the Crau (South of France) with the prototype (Astuce \& Tic, 2011) and some elements for structuring it in a framework (the PRECOS approach) applicable in other geo-socio contexts.

\section{Methods}

\subsection{The basic concept}

The basic idea is that urban sprawl cannot be considered separately from its immediate rural environment, i.e. its hinterland (Trolard et al., 2010, Trolard et al., 2013b). The circular causality chain DPSIR (Drivers - Pressure - State - Impact - Response) elaborated by the OECD (2003) is the working basis of the framework: human activities exert pressures over the environment and modify the quality and quantity of natural resources. Society reacts to these changes by adopting protection, limitation, confinement, depollution measures... and the cycle starts over again. The objective is of course to prompt a virtuous cycle.

\subsection{Devising the software's architecture}

The fields covered by the PRECOS approach comprise land occupation changes, soil sealing levels, agronomic qualification of soils, water geo-chemistry, fresh water needs according to the availability of resource and agricultural production requirements (Fig. 1a).

The selected models have already proven their efficiency in their respective fields. PRECOS integrates them all in an overall scheme (Fig. 1b), ensuring a global approach.

Both METRONAMICA (White and Engelen, 1993; White et al., 1997; Straatman et al., 2004) and URBANSIMUL (Géniaux, 2011) compute land occupation changes over time. In METRONAMICA, this transformation is achieved by the use of a cellular automaton coupled with a GIS, which constraints are defined by urbanization (distance to water, electricity networks, transport infrastructures...). URBANSIMUL uses probability tests of mutation of 
135 plots into urbanization based on tax data. The parameters, obtained from the analysis of the 136 results of both software, measure and represent the territory of a land use conversion into 137 another (natural, agricultural, urban and/or industrial areas and infrastructures), the share of 138 coastline affected by urbanisation and fragmentation of natural areas.

139

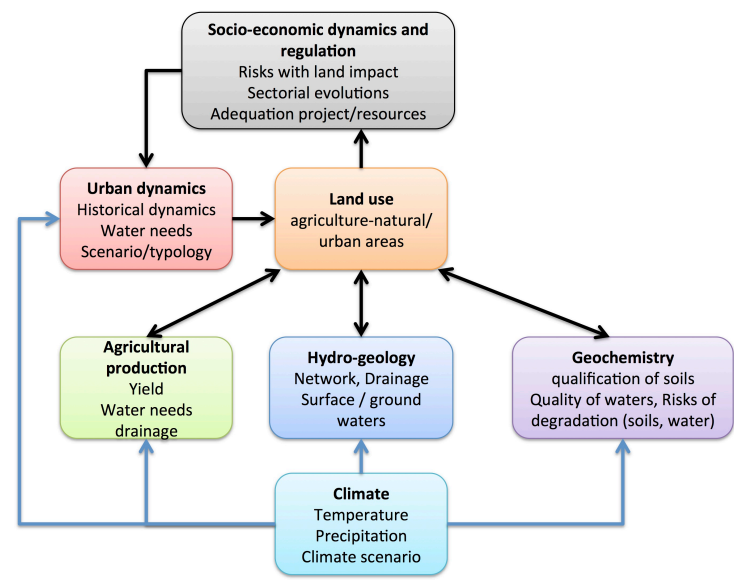

(a)

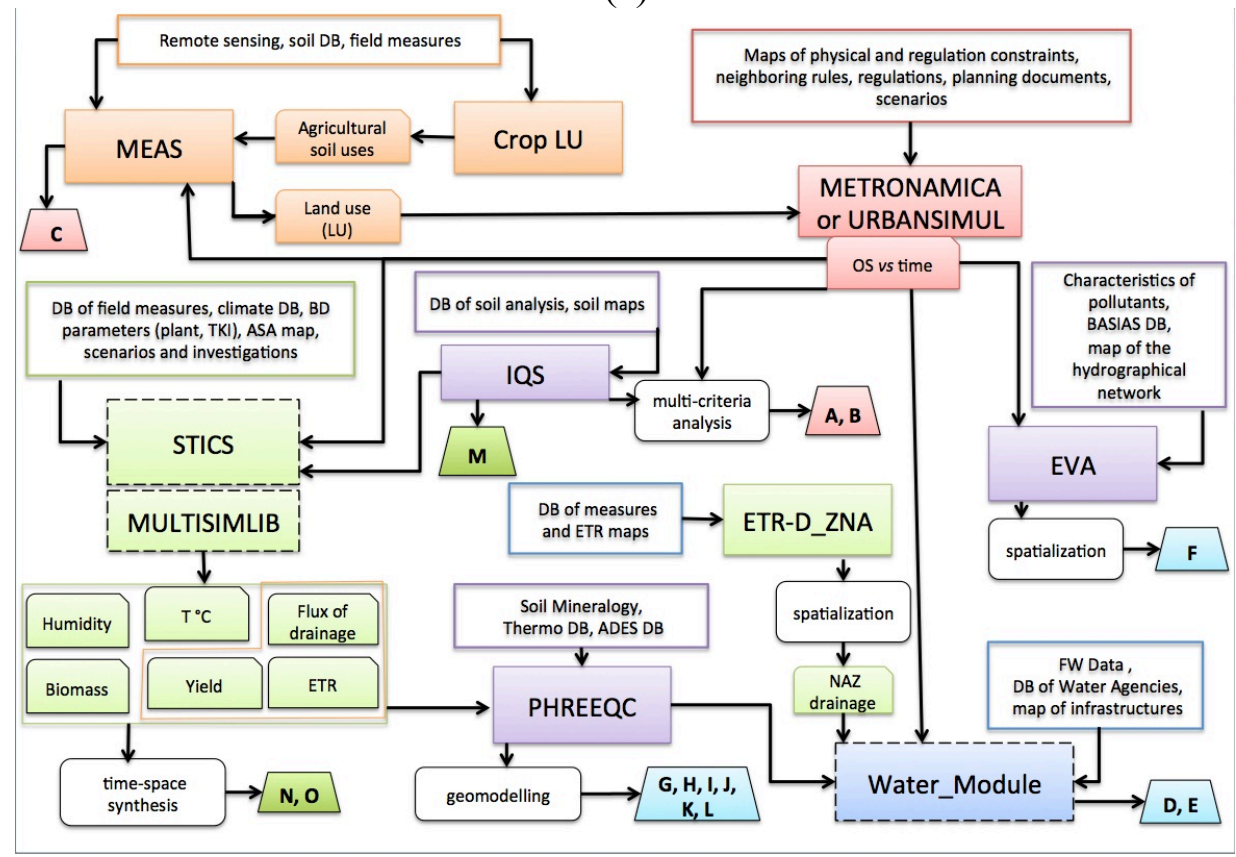

CAPTION

Software module

Processes of information and treatment

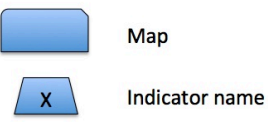

(b)

Figure 1: (a) Scheme of interconnections (black arrows) of the different domains considered in PRECOS approach; blue arrows indicated where climate parameters were explicitly taking into account and, (b) declination of this schema in the software architecture in Astuce \& Tic's prototype. 
The method of Assessment of Soil Artificialisation (MEAS) (Astuce \& Tic, 2011) takes into account the diversity and agronomic qualification of soils (SQI) (Balestrat et al., 2011), soil sealing and urban sprawl, including the fragmentation of agricultural lands. This approach is complemented by the EVA3 software (developed at Lausanne University) assessment of polluted sites and soils, which estimates the risk of soil contamination by industrial activities. MEAS and EVA produce spatially distributed typologies of artificial soil as well as input data for METRONAMICA or URBANSIMUL.

STICS (Brisson et al., 2003; Brisson, 2008) is a crop model that simulates crop biomass production, agricultural yields, water and nitrogen requirements, surface water flows and drainage (water percolation below the root zone). Calculations are made at the field plot level and aggregated on the territory with MultiSimLib model (Buis et al., 2011). The model is driven by climate parameters, which allows for taking into account climate change scenarios.

PHREEQC software (Parkhurst and Appelo, 1999) is a thermodynamical model for processing water chemistry data. It allows for the construction of geochemical indicators of water quality (potability, salinity, sodicity...) and the study of soil - solution interactions (geochemical changes, salinization, sodisation and stability of clays...).

For the spatial representations of data and results, specific visualization software (Mapinfo $\left.{ }^{\circledR}, \operatorname{Arcview}{ }^{\circledR}, \operatorname{Arcgis}{ }^{\circledR} \ldots ..\right)$ and a geo-modelling tool (gOcad $\left.{ }^{\circledR}\right)$ have been implemented. gOcad ${ }^{\circledR}$ software, developed by oil and mining geologists (Mallet, 2002) is more specifically capable for mapping heterogeneous and incomplete data (mesh conditional objects, interpolation functions and specific kriging, 3D visualization...). It has been adjusted to the requirements of territorial data mapping such as land distributions, soil properties, the geometry of soil horizons and of the aquifer, groundwater quality, land uses... (Astuce \& Tic, 2011). This software can produce thematic maps in 2D and 3D as well as spatial statistical analysis.

The above-mentioned software retain all the properties that might come in handy for subsequent in depth sector based studies. The constraint of building a tool around this system requires the pooling of scientific and technical expertise necessary to use it, define and produce the indicators. A Web portal presents the results in the form of maps, tables, curves or diagrams, which are accessible to end-users (e.g. decision-makers, stakeholders or local authorities), upon request, via key words.

\subsection{Sources of data}

Territorial data are abundant but also extremely scattered, very heterogeneous in space and/or time, albeit lacunar. At times, they can be accessed easily via open Web portals but quite often they only exist as paper records. The INSPIRE directive is currently driving many European regions to collect data, organise their regional databases around a homogeneous grid and make the information it contains available for free, especially when it belongs to the public domain (INSPIRE, 2007). Setting up a geo-database for the Crau plain involved quite a lot of information collection and computerization work. Data concern soil occupation, soils characteristics, geochemical qualities of soils and waters, climate, agricultural activities, demography, industrial sites characteristics, networks of water distribution. Different data production methods were implemented: extraction and assembling of information, layout, 
geo-referencing and digitization of documents, new data acquisition either via specific commands (e.g. remote sensing pictures), or by in situ measurements and laboratory analysis (e.g. soil thickness in grasslands, chemical composition of irrigation water...).

\subsection{Indicators}

The PRECOS approach combines heterogeneous data to produce indicators in three domains: soil degradation, water and soil resources and agriculture production. Today PRECOS is operational and set up to generate 15 indicators (Table 1). The modularity of the software's architecture allows for adding or selecting pertinent indicators as function of the local characteristics of the area under consideration.

Table 1: List of indicators produced by PRECOS's approach

\begin{tabular}{|c|c|c|}
\hline & Indicators & Definition \\
\hline A & Land occupation & $\begin{array}{l}\text { Typology of soil occupations: } 30 \text { classes categorised as urban and } \\
\text { non-urban environments, surface texture and specific classes } \\
\text { (resulting of merge of previous defined classes) for } \\
\text { METRONAMICA software, which is able to calculate only with } \\
15 \text { classes. }\end{array}$ \\
\hline B & Fragmentation of habitats & Measure the discontinuities in natural areas. \\
\hline C & Soil sealing & Soil-sealing ratio in \% per surface unit. \\
\hline D & Aquifer evolution & Variation of the aquifer's water volume and flows. \\
\hline $\mathbf{E}$ & Drinking water supply & $\begin{array}{l}\text { Supply / demand balance checks per infrastructure (drilling point } \\
\text { and connection to the fresh water supply networks). }\end{array}$ \\
\hline $\mathbf{F}$ & Pollution risk & $\begin{array}{l}\text { Vulnerability of industrial activity: potential of dangerous } \\
\text { substances per site, mobilisation potential of environmental } \\
\text { assets: air, soil, surface water and groundwater, exposure of assets } \\
\text { in need of protection. }\end{array}$ \\
\hline G & Water drinkability & $\begin{array}{l}\text { Estimation of the risk of non-drinkability from physical and } \\
\text { chemical characteristics of waters. }\end{array}$ \\
\hline $\mathbf{H}$ & Risk of water salination & $\begin{array}{l}\text { Calculation depending of the Ionic force and / or electrical } \\
\text { conductivity of waters. }\end{array}$ \\
\hline I & Risk of soil salination & $\begin{array}{l}\text { Estimation of the risks of precipitation of soluble sodium salts, } \\
\text { gypsum and salts more soluble than gypsum. }\end{array}$ \\
\hline $\mathbf{J}$ & $\begin{array}{l}\text { Risk of soil acidification } 1 \\
\text { (calculated with water data) }\end{array}$ & $\begin{array}{l}\text { Calculation of the water saturation index compared to calcite } \\
\text { precipitation. }\end{array}$ \\
\hline $\mathbf{K}$ & $\begin{array}{l}\text { Risk of soil acidification } 2 \\
\text { (calculated with soil data) }\end{array}$ & Calculation of the "active lime" contents in soils. \\
\hline $\mathbf{L}$ & Risk of soil sodicity & Calculation of Sodium Adsorption Ratio (SAR) as an indicator of \\
\hline
\end{tabular}


M Soil agronomic qualification index

N Agriculture production

O Drainage soil structure degradation.

Assessing the qualification of soils for agriculture use.

Calculation of yields and biomass products of the different crops.

Quantification and localisation of waters drained per surface unit.

\subsection{The scenarios' construction method}

The PRECOS approach makes a distinction between «constraints» such as climate, economic climate upon which local actors have little influence and "levers" on which actors can exert some degree of influence such as zoning, land acquisition... (Trolard et al., 2013b). The medium-term was chosen for the scenarios because it is a time horizon where preventive and adaptive actions are still possible. By providing an "a minima" representation of pressures and some notion of additional costs incurred for coping with them, these scenarios can help stakeholders to remain under the threshold beyond which damages to strategic resources will be irreversible. Indeed, in a space with limited resources, pressures are to a large extent predetermined and respond, at this horizon, to rather rigid dynamics determined by geography, regulation, demography, real estate market logics, infrastructure and economic activities.

Table 2: Standard questionnaire used for the test cases

\begin{tabular}{|c|c|}
\hline Domains & Questions or needs \\
\hline Socio-economic context & $\begin{array}{l}\text { Rough description of the main economic sectors focusing on agriculture, industry } \\
\text { and urbanization }\end{array}$ \\
\hline Local vulnerability & $\begin{array}{l}\text { Are urban sprawl and/or soil sealing problems in your area? } \\
\text { Is it exerting pressure over other sectors, e.g. the consumption of fertile land for } \\
\text { food production? } \\
\text { Can you identify a hot spot area where to study these relations and related problems } \\
\text { and solutions? } \\
\text { Is climate change affecting local resources, and main economic sectors? } \\
\text { Which are the main climate related problems for agriculture, urban areas and } \\
\text { industries? } \\
\text { (General and rough answers also.) }\end{array}$ \\
\hline $\begin{array}{l}\text { State of the art of current } \\
\text { tools }\end{array}$ & $\begin{array}{l}\text { Are there similar tools already available in your territory? } \\
\text { Which tool managing water use, soil use, soil quality, urban development, e.g. } \\
\text { irrigation advice or water use in industry and urban areas? Who is the owner? Who } \\
\text { is running it? Is the result for free? } \\
\text { Are they considering an inter-sectorial approach or are they only sector based? } \\
\text { Is the local government feeling the need to have a tool, which is able to integrate all } \\
\text { sectors using land and water resources? } \\
\text { (General and rough answers also with a simplified table.) }\end{array}$ \\
\hline Territorial data & $\begin{array}{l}\text { PRECOS needs to use mainly geographical data, e.g. data on soil and water quality, } \\
\text { water use, land use, urban trends, hydrology etc. Are these data easily available? } \\
\text { Who is the owner? What is the overall spatial resolution? Are they free? } \\
\text { (General and rough answers also with a simplified table) }\end{array}$ \\
\hline
\end{tabular}


Main vulnerability and linked indicators

Conclusion
Astuce \& Tic (A\&T) is the first version of PRECOS approach. The prototype is able to release a list of indicators, which were specifically required in the demonstration area, the Crau area.

Which are important locally and which one are missing? Are they obtainable using current available data?

Mainly state the reason for which the application of PRECOS can be important.

This kind of simulation made by iteration does not take into account major events likely to change drastically the land occupation (e.g. natural hazard, political decision). However, the PRECOS approach can re-initialize its tools in such a way that if needed, this new occurrence might be included and accordingly a new simulation achieved.

\subsection{Up-scaling of the PRECOS approach in other contexts}

To assess whether the PRECOS approach could be deployed in different geo- and socioeconomic contexts typical situations where urban sprawl and climate change may critically jeopardize local resources were identified and explored. This involved extensive discussions, interviews and exchanges with local decision-makers, stakeholders, engineers and researchers in Italy, Spain and France and the completion of a questionnaire (Table 2).

\section{Demonstration area: the Crau plain}

Covering a surface of approximately $600 \mathrm{~km}^{2}$, the Crau plain is delineated by the Alpilles in the North, the Rhone River in the West, the Mediterranean Sea in the South, and in the East, the Etang de Berre and the La-Fare-les-Oliviers short mountain chain (Fig. 2). The climate is meditarranean (rainfall is less than $600 \mathrm{~mm} \mathrm{year}^{-1}$ ), the tree cover quasi nonexistent and the Mistral wind blows regularly with great violence. 


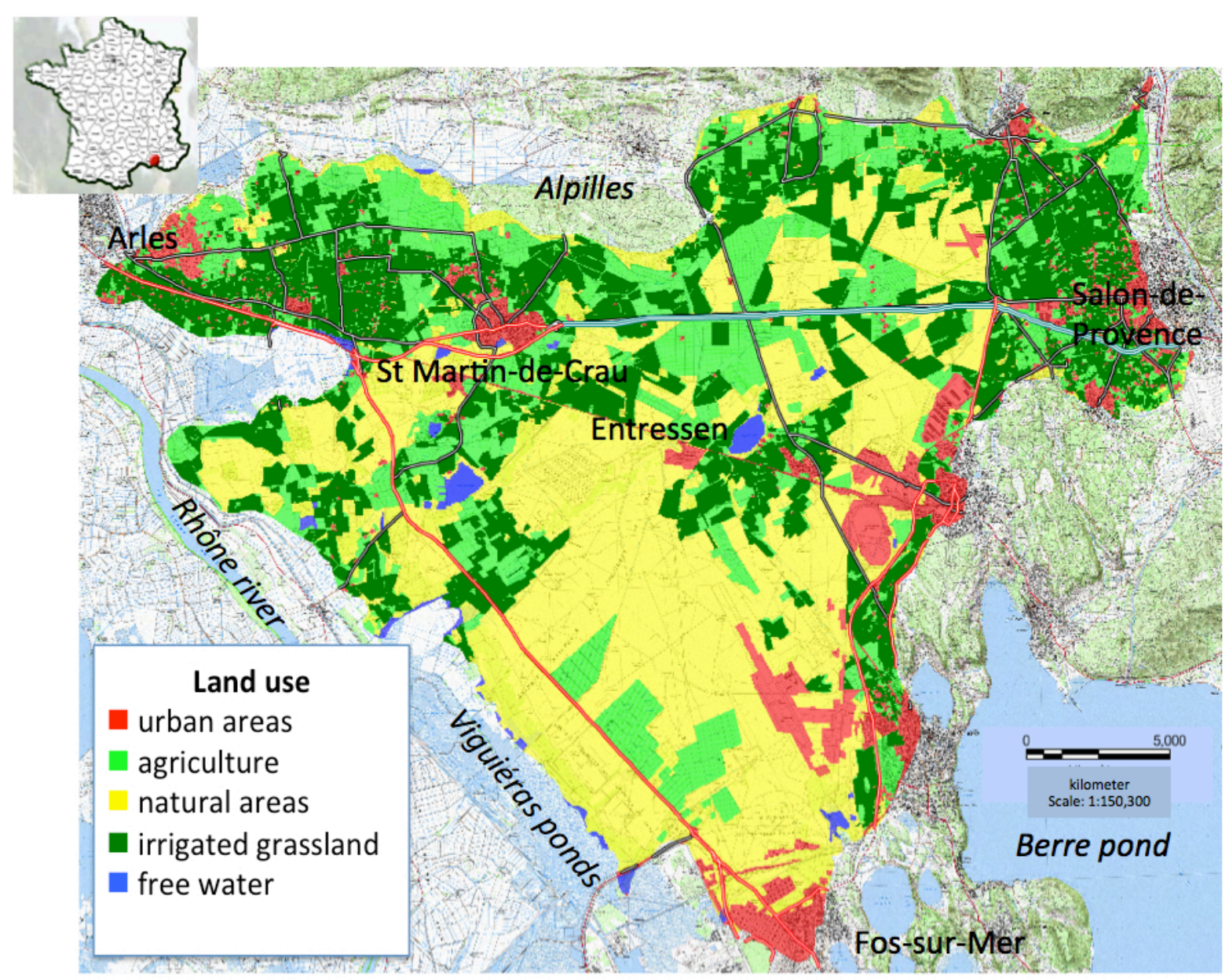

Figure 2: Map of the Crau territory

The natural Crau landscape is a steppe of 9,200 ha called the " dry Crau »; its ecosystem is unique (forming a natural, cultural and economic exception at local, regional and European levels), with exemplary endemic organisms of special conservation interest (Wolff et al., 238 2013).

239 The Crau's irrigation system dates back to the $16^{\text {th }}$ century. Thus for over 400 years, through gravity irrigation, the system brought the Durance water and silt over the Crau's gravel. It covers nowadays a surface of 12,500 ha mainly devoted to producing "Crau hay", a PDO (Protected Designation of Origin) and sheep rearing, especially that of the PGI

243 (Protected Geographical Indication) labelled the "Sisteron lamb" and "Merinos from Arles".

244 Locally, part of the pastoral land has been given over to intensive orchards and greenhouse vegetable production, most of the irrigation water for these activities being provided by directly pumping into the aquifer or by drip irrigation (Bonfillon, 2008). These irrigation waters contribute over $75 \%$ the Crau's groundwater recharge and supply drinking water to approximately 280,000 people as well as to the large industries established at the south of the area. 


\begin{tabular}{ll}
\hline Scenario 0 & Called "trend" scenario is the scenario that translates the weight of existing \\
constraints over the area and population. The evolution of indicators is \\
obtained by the linear extrapolation up to 2030 of the historical socio- \\
economical evolutions registered over the $1997-2009$ period. \\
Ccenario 1 \\
Called the "industrial consolidation and diversification" scenario, assumes a \\
strong industrial development in the South of the area, with as hypothesis that \\
the maritime Great Marseille harbour is the epicentre. This leads to the \\
extension of industrial areas receiving high-risk activities and increases soil \\
sealing. \\
Called the "development of services and residential activities" scenario, \\
assumes an important development in services activities in the North, along \\
the Arles - Salon-de-Provence axis, and a stagnation of industrial activities in \\
the South. This scenario examines especially the difficulty to combine \\
development constraints, existing regulatory frameworks in such risk prone \\
areas, with high land-consumptive activities such as logistics and residential \\
activities dedicated to the tourism. \\
Climate scenario Alb over 2025-2035 period calculated with reference data \\
(temperature, precipitation) over 2001-2010 period. \\
Estimation of reduction of water resource for irrigation of 30\%. \\
Climate and water constraints
\end{tabular}

In the Crau area, the constraints appear particularly strong given that four factors currently guide the regional planning choices: (i) a demographic pressure that is not counterbalanced by a socio-economic dynamic growth; (ii) competition for access to land and local resources in an area marked by important physical constraints and vulnerabilities and a particularly high exposure to risks; (iii) the pervasiveness of very international economic activities with weak regional links but strong environmental footprint and an investment backlog in infrastructure (transport, energy) that increase the areas' marginalization from the main global trade routes and (iv) a legislative and regulatory framework that is supposed to offer in theory a high level of protection but only provides in practice, a low level of safety. This points towards a more rational use of resources (soils, water) (Trolard and Dangeard, 2014).

The regional climate change in Crau, as defined by IPCC's Alb scenario (Pachauri and Reisinger, 2007) and on the basis of long-term meteorological records (Olioso et al., 2013a), consists in: (i) a temperature increase well established since 1980 with a rate of $0.5^{\circ} \mathrm{C}$ every 10 years; (ii) no significant change in annual precipitation since the beginning of the $19^{\text {th }}$ century; (iii) a recent increase of reference evapotranspiration ETo, computed using the FAO56-PM method (Allen et al., 1998) around $1.5-2 \mathrm{~mm}_{\text {year }}{ }^{-1}$. A decrease of water resources for agriculture is to be expected from now to 2030, caused by a new allocation of water resources, due to the increasing competition between (i) maintaining a sufficient flow of water in dry periods and (ii) satisfying the demand for energy production, industrial and touristic needs.

Scenarios for Crau area were defined in Table 3. The situation of reference for the all the variables is defined by the values of the year 2009. The calibration of the dynamics of the models' parameters was made with reference to the land occupation's evolution between 1997 


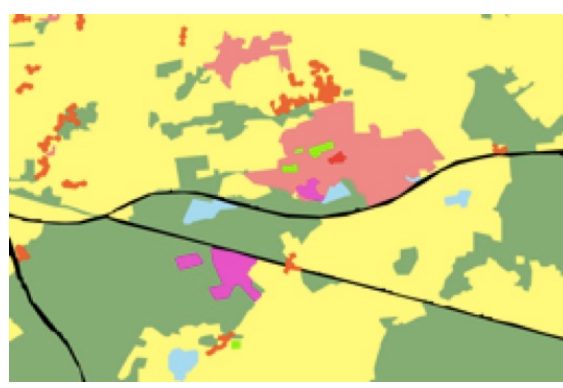

a

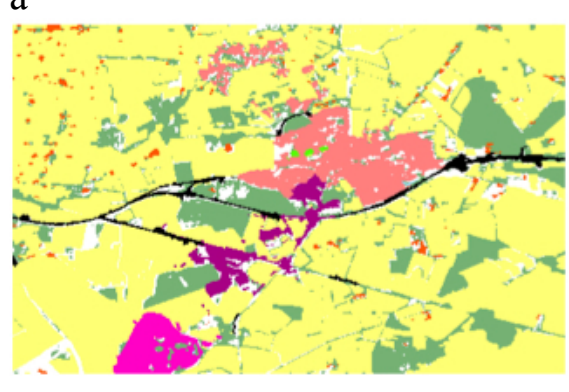

c

Figure 3: Land use maps: it shows ( $a, b)$ how urban development is reflected in the Corine Land Cover mapping and $(c, d)$ how it appears when the PRECOS approach is applied for one of the municipalities of the Crau area in 1997 and 2009 respectively (from Trolard et al., 2013b).

During the 1997-2009 period over than 1,600 ha of irrigated grasslands and natural areas were lost to urban sprawl and the implementation of environmental measures is undermined by the "fait accompli" (Fig. 3).

Evidence for this was obtained by devising extremely fine land occupation maps of the Crau area between 1997 and 2009 (spatial resolution of $0.6 \mathrm{~m}$ to $20 \mathrm{~m}$ depending on the location in the area) (Fig. 3 c, d). Indeed, the data from CORINE Land Cover, as already observed by other authors (Pageaud and Carré, 2009), do not meet the needs of urban planning. This can be ascribed to the low resolution of the mesh used by CORINE Land Cover and to the fact that the classification of land uses is not stable over time. This makes it impossible to superimpose maps drawn on two different dates (Fig. 3a, b). The study covering the entire Crau area thus shows that between 1997 and 2009, urban sprawl has affected approximately 2,300 ha. Similar observations were made in Italy (Biasoli et al., 2006), more largely in Mediterranean region (Salvati, 2014) and in Asia (Zhang et al., 2007). Observations in the Emilia-Romagna region in Italy have shown that over the 6-year period (2003-2008) urbanization led to a loss of crop production potential equivalent to the daily caloric 
requirements of more than 440,000 people (Malucelli et al., 2014). In addition, the National Strategy for Sustainable Development for 2010 - 2013 has highlighted as one of its objectives the need to ensure that the land sealing rhythm, which is currently superior to demographic dynamics, must be better controlled especially by endeavoring to locate the new infrastructures on lands already artificialized (DIDD, 2010).

4.2 Multi-secular irrigated agriculture: a factor of sustainability and a source of ecosystem services

Thanks to Adam de Craponne's canals built in the Crau area, in the $16^{\text {th }}$ century, the multisecular irrigation system warrants a lasting resilience of the biophysical environment. This is demonstrated by the integrated analysis of the agronomical, pedological, land use and biogeochemical soil and water data (Trolard et al., 2013a).

The geochemical study shows that the Durance waters used for irrigation do not have any aggressive effect on the soil mineral components and instead, meet most of mineral nutrients necessary to the Crau's hay. A comparative balance between the concentration of mineral elements exported by the Crau's hay and the rates of mineral matters found in the irrigation waters only reveals a slight deficit for potassium and phosphorus (Table 4) (Bourrié et al., 2012).

Table 4: Balance of mineral element fluxes brought by the irrigation water compared to the needs of Crau's hay for the first cut.

\begin{tabular}{lllllcc}
\hline Element & $\mathrm{Ca}^{2+}$ & $\mathrm{PO}_{4}{ }^{3-}$ & $\mathrm{Mg}^{2+}$ & $\mathrm{Na}^{+}$ & $\mathrm{SO}_{4}{ }^{2-}$ & $\mathrm{K}^{+}$ \\
\hline Balance* & 1.41 & -0.02 & 0.30 & 0.31 & 0.47 & -0.14 \\
\hline
\end{tabular}

In the Crau plain, irrigated agriculture for over 400 years, has contributed to four essential ecosystems services: (i) soil conservation; (ii) biomass production; (iii) aquifer recharge and (iv) wetland preservation.

\subsection{Soil conservation}

Irrigation has two consequences. It brings silt, thus changing the soils' granulometry. It changes soils' acido-basic properties because of the geochemical interactions between waters and soils. The Durance irrigation waters protect soil against its natural trend towards acidification caused by rainwater. When rain enters the topsoil, its acid properties are enforced because it equilibrates with $\mathrm{pCO}_{2}$ of soil atmosphere, which is much larger than $\mathrm{pCO}_{2}$ of external atmosphere; it operates then as a strong solvent. In the Crau area, irrigation waters contain dissolved calcium carbonate because of their transfer from the Alps through limestones, and their $\mathrm{pH}$ is of 8.3. This makes them less aggressive towards soils minerals and even instead, makes them rather encrusting depending on the degree of concentration of water by evaporation, which depends itself on climatic conditions.

\subsection{Biomass production}


Two parameters are critical for determining the grassland's yield: the soils' characteristics and the water turns, i.e. time between two irrigations and water quantity per irrigation

344 (Astuce \& Tic, 2011). The average yields vary between $7.8 \mathrm{t} \mathrm{ha}^{-1}$ and $9.7 \mathrm{t} \mathrm{ha}^{-1}$ (Comité du 345 Foin de Crau, personal communication). The highest yields are obtained on hydromorphic

346 soils or on soils, which have the thickest HA horizon, i.e. soils with the highest water holding 347 capacity. The productivity is also dependent on the water turns: the greater the intervals, the 348 lower the yields.

\subsection{Aquifer recharge}

The large permeability of the aquifer in the Crau $\left(10^{-3}\right.$ to $\left.10^{-2} \mathrm{~m} \mathrm{~s}^{-1}\right)$ and massive inflows of water by irrigation (about 20,000 $\mathrm{m}^{3} \mathrm{ha}^{-1}$ year $^{-1}$ ) define a highly dynamic regime of the aquifer. Thus even though irrigated grasslands occupy less than $20 \%$ of the Crau plain's surface, they contribute to over $75 \%$ to the aquifer's water replenishment. The sporadic but regular charging, which comes from irrigated grasslands, actively supports the groundwater levels observed. In the North the piezometrical variations under some irrigated areas can reach $10 \mathrm{~m}$ (Baillieux et al. 2015). Water charging by irrigation is smaller in grasslands on hydromorphic soils and the average recharge of water is $1,337 \mathrm{~mm}_{\text {year }}{ }^{-1}$, while on other types of soils it is over $1,700 \mathrm{~mm}^{-1}$ yer $^{-1}$. As the average thickness of the aquifer is between 10 and $40 \mathrm{~m}$, the operational capacity to use the underground water resources is highly dependent on the conduct of the gravity irrigation of grasslands.

\subsection{Wetland conservation}

Gravity irrigation for agriculture has a predominant influence on surrounding wetlands. It maintains the overflow of groundwater upstream from the aquifer. These waters then reappear under the form of resurgences feeding the surrounding ponds (Entressen and Des Aulnes) and wetlands, known for their large ecological diversity (Vigueirat pond), 1,000 ha of which are classified as a biosphere reserve. Gravity irrigation thus maintains a hydrostatic balance preventing the salted aquifer to ingress from the South (Fig. 2).

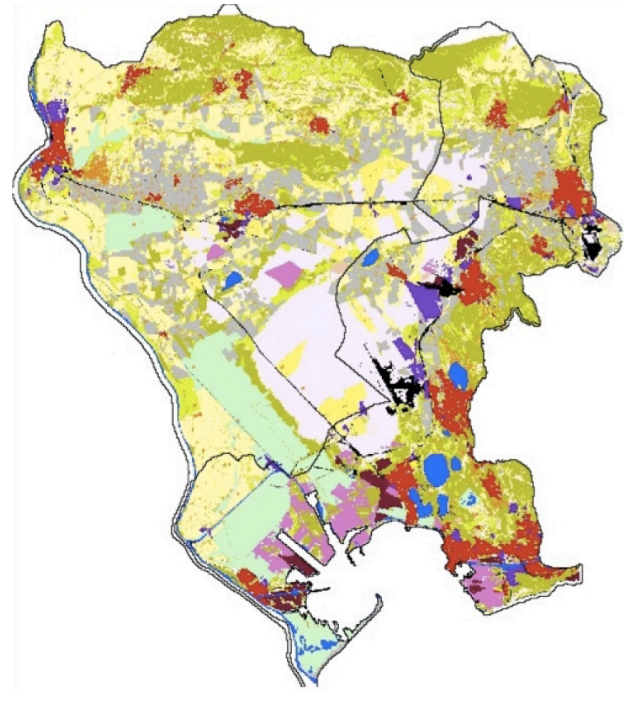

$\mathrm{a}$

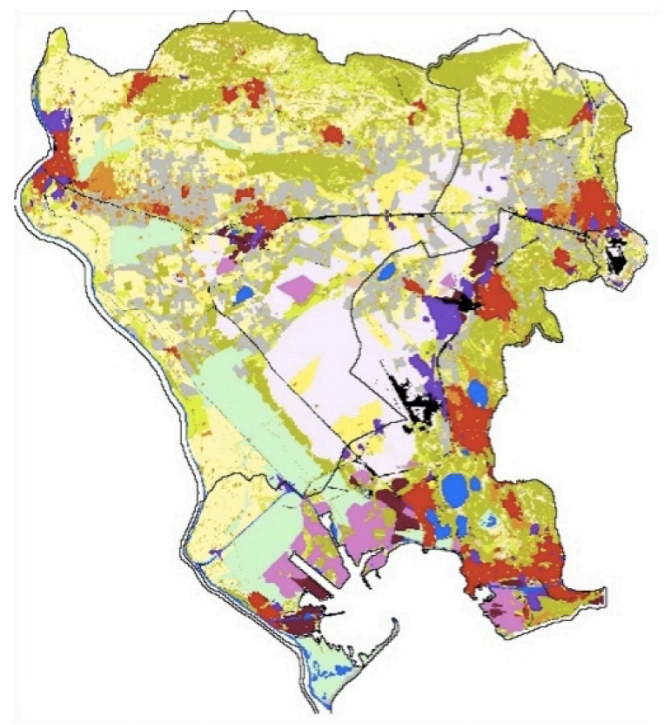

b 


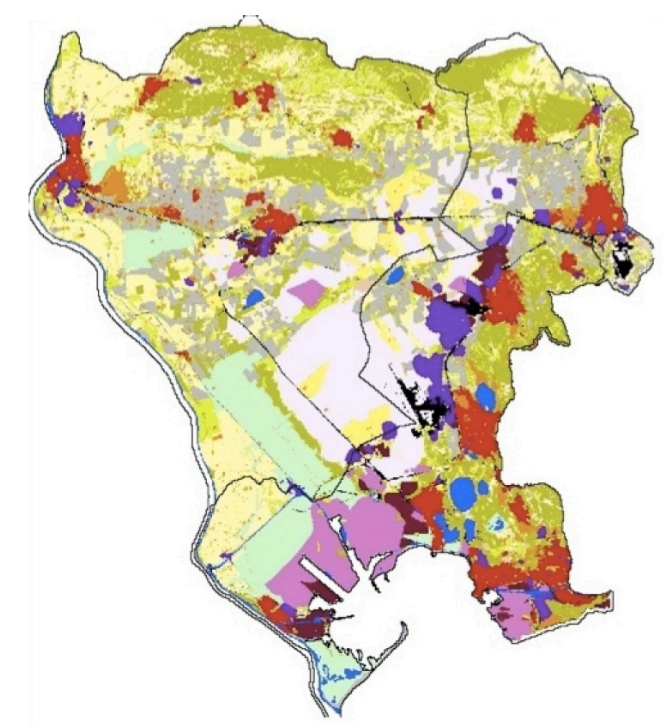

c

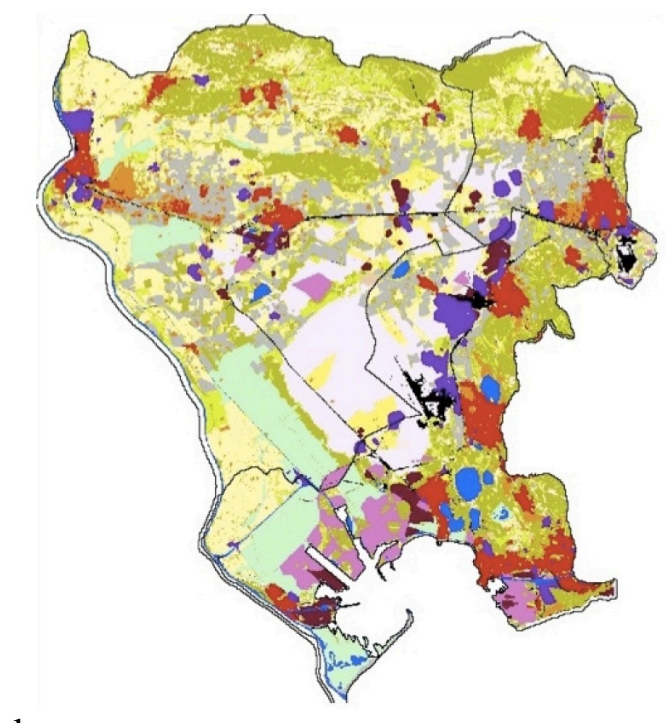

d

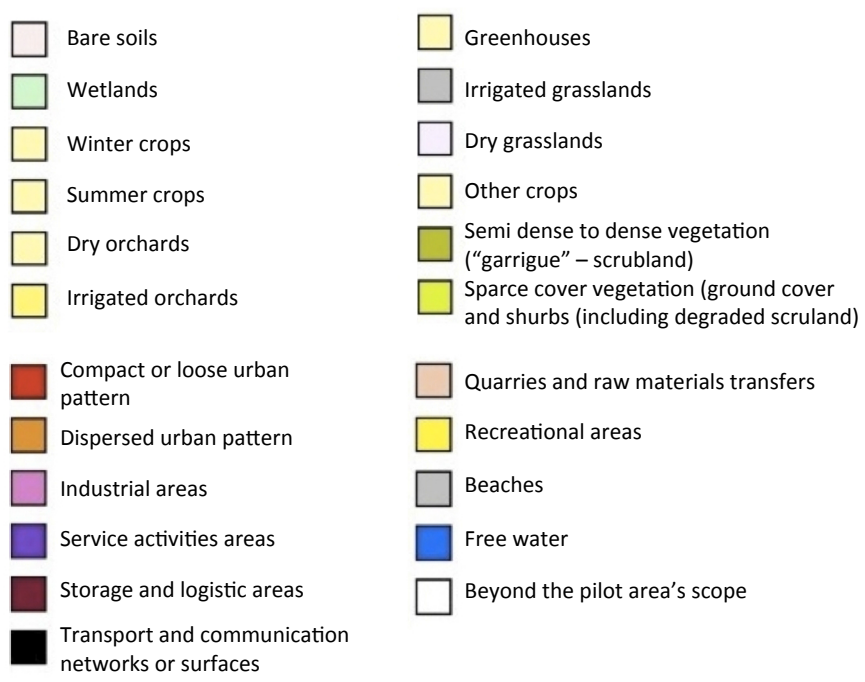

Figure 4: Prediction of land occupation change in 2030 as function of the different scenarios. (a) reference 2009, (b) 2030 - scenario 0, (c) 2030 - scenario 1 and (d) 2030 - scenario 2.

Furthermore, the supply of calcium by irrigation water percolating through the soil and sub-soil down to the aquifer contributes to the groundwater's high quality, by precipitating the excess of phosphate in the form of apatite (calcium phosphate) preventing any eutrophication of the aquatic systems (Bourrié et al., 2012).

\subsection{Perspectives to 2030 in the Crau area}

At the 2030 time horizon and whatever the scenario, simulations show an increase of the territory's vulnerability and significant alterations of ecosystem services provided by agriculture.

Results show that urban sprawl will happen at the expense of protected natural areas, cropped lands and irrigated grasslands (Table 5, Fig. 4). Land surface lost to urbanization ranges between 4,377 ha for scenario 0 ("trend" scenario) and 7,358 ha for scenario 2, the 
Table 5: Estimate of surface areas that will be used up by urbanization between 2010 and 2030 by type of land occupation as function of the three scenarios. The surfaces are expressed in hectares and in \% of the total surface of the considered soil occupation.

\begin{tabular}{lrrrrrr}
\hline \multirow{2}{*}{ Type of Soil Occupation } & \multicolumn{2}{c}{ Scenario 0 } & \multicolumn{2}{c}{ Scenario 1 } & \multicolumn{2}{c}{ Scenario 2 } \\
& /ha & \multicolumn{1}{c}{$/ \%$} & /ha & \multicolumn{1}{c}{$/ \%$} & \multicolumn{1}{c}{ ha } & \multicolumn{1}{c}{$\%$} \\
\hline Irrigated grasslands & 1,065 & 6.8 & 1,308 & 8.3 & 1,826 & 11.5 \\
Great field crops & 23 & 0.2 & 43 & 0.4 & 62 & 0.6 \\
Other crops & 38 & 0.9 & 64 & 1.5 & 222 & 5.2 \\
Dry meadow & 113 & 0.9 & 585 & 4.6 & 563 & 4.4 \\
Natural areas* & 1,341 & 3.9 & 2,863 & 8.4 & 1,813 & 5.3 \\
Wetlands & 173 & 1.8 & 694 & 7.4 & 293 & 3.1 \\
Orchards & 147 & 2.3 & 332 & 5.3 & 798 & 12.7 \\
Bare soil & 1,473 & 21.0 & 1,916 & 27.3 & 1,778 & 25.3 \\
TOTAL & 4,376 & & 7,805 & & 7,356 & \\
\hline
\end{tabular}

* out of wetlands

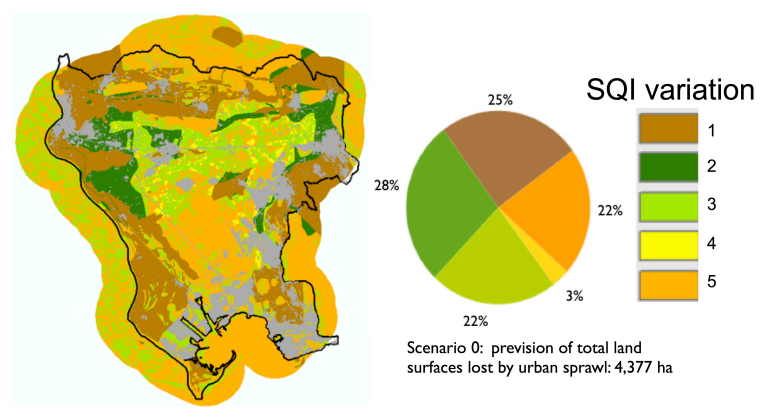

Figure 5: Qualification and quantification of soils loosed to urban sprawl: results obtained for 2030 with the scenario 0. Soil Qualification Index (SQI): 1. Hydromorphic soils; 2. Soils with $50 \mathrm{~cm} \mathrm{HA} \mathrm{horizon;} \mathrm{3.} \mathrm{Soils} \mathrm{with} 35 \mathrm{~cm}$ HA horizon; 4. Soils with $10 \mathrm{~cm} \mathrm{HA} \mathrm{horizon;} \mathrm{5.} \mathrm{Fersialitic} \mathrm{soils.}$

393

394

395

396

397

398

399

400

401

402

403

404

most space-consuming scenario. In all cases urban sprawl impacts over $50 \%$ of the most a these lands correspond to the oldest irrigated grasslands where soils are the result of over 400 years of cumulated silt deposits. 


\begin{tabular}{|c|c|c|}
\hline Occupation by default & 10.0 & 10.0 \\
\hline Coussouls and sparse vegetation & 32.8 & -7.6 \\
\hline Irrigated grasslands & $2,020.0$ & $1,464.0$ \\
\hline Summer crops (e.g. sunflower) & 86.4 & 125.0 \\
\hline Winter crops (e.g. wheat) & 63.6 & 54.6 \\
\hline Wetlands* & -316.0 & -491.0 \\
\hline Orchards & -316.0 & -434.5 \\
\hline \multirow[t]{2}{*}{ Water allocation } & \multicolumn{2}{|c|}{ Withdrawals (millions of $\mathrm{m}^{3}$ year $^{-1}$ ) } \\
\hline & Reference 2009 & Prediction 2030 - scenario 2 \\
\hline Drinking water & 24.8 & 32.2 \\
\hline Industrial water & 7.6 & 7.6 \\
\hline Agricultural water & 27.0 & 21.8 \\
\hline
\end{tabular}

In addition, simulations of the water table level for 2030 show an important drawdown explained by the conjunction of an anticipated decrease of irrigated grassland surface in the range of $11 \%$, a decline of about $30 \%$ of irrigation water quantities from Durance River and $30 \%$ increase of drinking water requirements (Fig. 6).

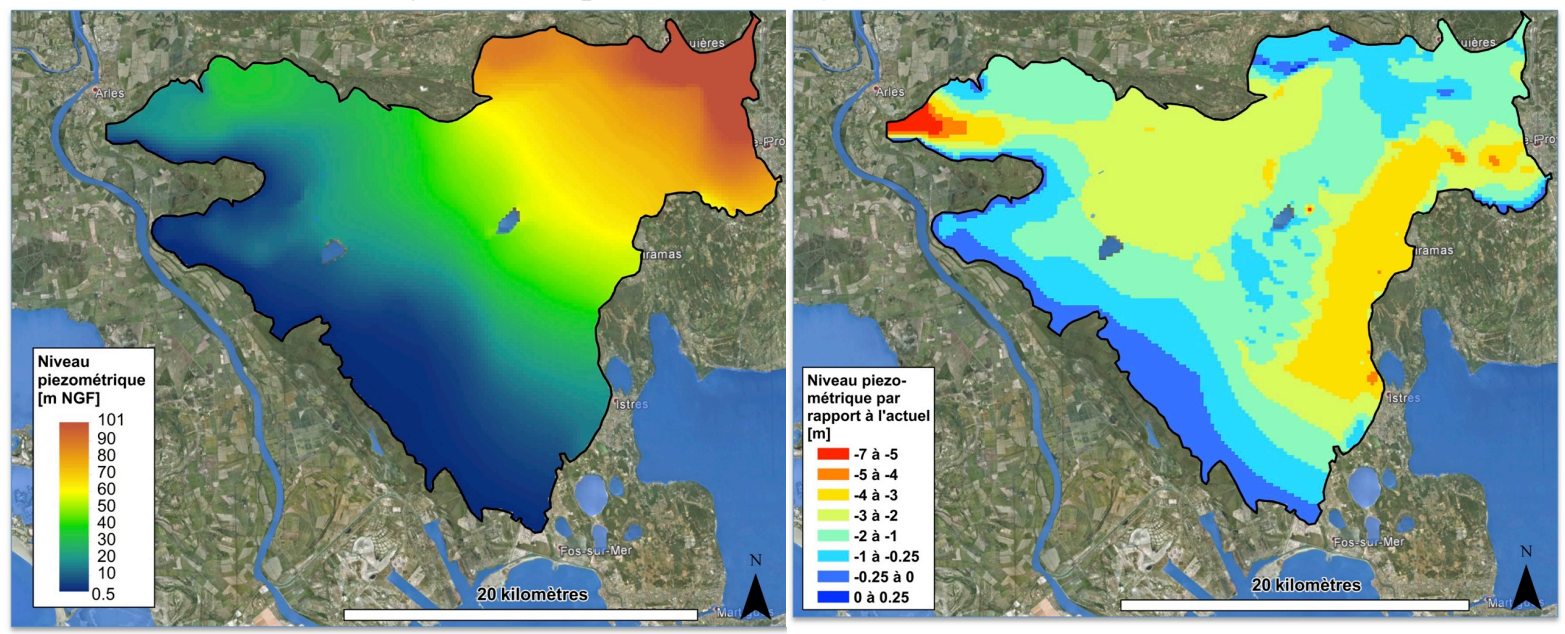

Figure 6: Piezometric level in permanent regime in reference state 2009 (a) and prediction of the evolution of the water table in permanent regime in 2030 with the scenario 2 (b) (from Olioso et al., 2013 b and Baillieux et al., 2015).

The main consequence for industry and cities would be water shortage, with a predicted lowering of the groundwater table ranging from 2 to $9 \mathrm{~m}$. If infrastructures must be built to bring pressurised water from the East of Provence, the additional cost will be huge.

The reduction of the aquifer expansion would have other drastic consequences with: (i) a possible progression inland of sea water ingress in the south of the territory and (ii) depriving

418 of wetlands of their fresh water supply entailing "catastrophic" impacts on local biotopes and 419 associated biocenosis. 
When looking at urban governance system typologies (Metrex, 2010), it is possible to observe that several broad geographical and resource conditions will be favourable for integrated approaches such as PRECOS: (i) important rural surfaces devoted to agricultural production and /or proximity of protected natural areas; (ii) strong urban sprawl whether or not linked to urban growth; (3) the proximity of environmentally taxing industrial (or commercial) installations or infrastructure (Seveso installations, logistic platforms, mines etc.) and (iv) specific developments, constraints or triggers related to the socio-economic or regulatory context.

Table 7: Main vulnerability and linked indicators $\left({ }^{*} A \& T=\right.$ Astuce \& Tic prototype $)$

\begin{tabular}{|c|c|c|c|c|}
\hline & A\&T* indicators & Crau & $\begin{array}{c}\text { Emilia- } \\
\text { Romagna }\end{array}$ & Valencia \\
\hline A & Land occupation & yes & yes & yes \\
\hline B & Fragmentation of habitats & yes & May be & yes \\
\hline $\mathrm{C}$ & Soil sealing & yes & yes & yes \\
\hline $\mathrm{D}$ & Aquifer evolution & yes & no & no \\
\hline $\mathrm{E}$ & Drinking water supply & yes & no & no \\
\hline $\mathrm{F}$ & Pollution risk & yes & May be, not easy & yes \\
\hline $\mathrm{G}$ & Water drinkability & yes & no & yes \\
\hline $\mathrm{H}$ & Risk of water salinity & yes & no & no \\
\hline I & Risk of soil salinization & yes & no & yes \\
\hline $\mathrm{J}$ & Risk of soil acidification (soil data) & yes & no & no \\
\hline $\mathrm{K}$ & Risk of soil acidification (water data) & yes & no & no \\
\hline $\mathrm{L}$ & Risk of soil sodicity & yes & no & yes \\
\hline M & Soil agronomic qualification index & yes & yes & yes \\
\hline $\mathrm{N}$ & Agricultural production & yes & yes & yes \\
\hline $\mathrm{O}$ & Drainage & yes & yes & yes \\
\hline \multicolumn{5}{|c|}{ Locally important indicators not included in A\&T } \\
\hline 1 & Carbon stock & & yes & yes \\
\hline 2 & Run off modification & & yes & yes \\
\hline 3 & Land capability & & yes & yes \\
\hline 4 & Air quality & & Data not ready & - \\
\hline 5 & Brown soil & & yes & - \\
\hline 6 & Eutrophisation & & - & yes \\
\hline
\end{tabular}

Consultations with potential end-users in regions of Emilia Romagna in Italy and Valencia in Spain have shown that the PRECOS approach can be deployed by using existing data and by organizing, at local level, a consortium of skills able to analyze the results. Table 7 shows that in these new test areas, indicators proposed by the PRECOS approach can be produced. If the local situation requires consideration of new indicators, the modularity of the processing chain allows for adding new modules and interfaces in the workflow.

The consortium had the opportunity to apply the first stages of the PRECOS approach in Emilia-Romagna, an Italian region identified as likely to encounter serious climate and resource pressures in the future. PRECOS has been identified as useful for policy makers, cautioning authorities and developers when planning for future land and water uses... The 
444 province of Modena was one of the areas earmarked as well adapted to the introduction of the 445 PRECOS approach. Indeed, in this province, urban sprawl problems are rendered even more 446 acute, because of on-going post-earthquake reconstruction operations especially those in connection to large scale transport infrastructure developments. Several studies have already shown the extension of the risks of soil sealing and climate change in the region (e.g. consequences and costs of runoff during extreme events, damages to the water network, soil degradation...) (Burrato et al., 2012; Ceccarelli et al., 2014; Salvati, 2014; Ungaro et al., 2014). Moreover, policy and decision-makers are quite aware of this especially considering the weight of high quality agriculture productions in the local economy.

In Valencia region, taking into account the complex scenario of future regional development with an increase of risks due to the climate change and a difficult balance between environment and economic growth (e.g. García, 2010; Rico-Amoros et al., 2009; Vicente Serrano et al., 2004; Luis et al., 2000), the PRECOS approach could play a significant role supporting decision-makers and politicians to make better decisions. The current lack of comprehensive tools capable of merging and managing different sources of geo-referenced data (social, economic, environmental) and of turning them into useful information for decision-makers has been emphasised.

\section{Conclusions}

Building on and elaborating from Astuce \& Tic prototype, the European consortium in charge of PRECOS established that the approach could be deployed beyond the Crau pilot demonstration area and was likely to meet the needs of a variety of local situations.

The Crau area was chosen because it is representative of critical situations deriving from global changes, urban pressures and climate change that are apparent in a number of places in the world. Conducting this experimental approach on the Crau area has shown that up to the beginning of the $16^{\text {th }}$ century local planning was developed around the Crau irrigation network. Irrigated grasslands were the cornerstones of the anthropic-system and an example of how successful men's multi-secular efforts were to maintain a balance with the environment.

The PRECOS integrated approach provides a global vision of urbanization and climate change' manifold impacts on all ecosystem services; it identifies hic et nunc the more vulnerable and risk-prone areas and takes into account the inter-relationships between all their components.

Method wise, the treatment or acquisition of new data and the integration of multi-sector information is pooled within a chain of modeling modules that generate pertinent and factual indicators for a given area and offer the possibility of following their dynamics in real time. Medium term scenarios then analyze the dynamics of these indicators overtime and lead to a virtual representation of what future adaptations could lead in terms of "a minima" pressures and potential additional costs before their cumulated impacts drive the area to tipping points. The representation tools make it possible to visualize these results in terms of time-space and also provide supporting documents for stakeholders' consultations, discussions or 
Pre-diagnosis made in regions of Emilia-Romagna (Italy) and Valencia (Spain) show that local end-users and policy-makers are interested by this approach. The modularity of indicator calculations and the availability of geo-databases indicate that PRECOS may be up scaled in other socio-environmental contexts. Moreover, on one hand, the efforts to build up regional databases following standardized guidelines defined at international level and, on the other hand, the development projects of the use of digital technologies in local communities mean that the data is becoming more accessible and free. In addition, the modular software architecture allows PRECOS (i) to evolve with advances in modeling sectors considered here; (Ii) to interchange a simulation module by an equivalent and more appropriate to the local context (iii) to integrate new features and compute new indicators based on the needs of stakeholders and policy-makers. PRECOS is a valuable tool to turn this data into actionable information for territorial management.

\section{Acknowledgements}

The conception of the prototype has mobilised numerous students and other contributors. Thus authors address many thanks to F. Baret, P. Beauclair, R. Bile, M. Conruyt, A. Dangeard, B. Descamp, J.C. de Mordant de Massiac, H. Erray, M. Fouletier, R. Hadria, A. Jan, F. Nawaz, J.C. Maho, F. Maurel, M. Mayor, T. Ménard, R. Lecerf, B. Le Pors, O. Pascal, P. Rosselo, F. Ruget, S. Viseur for their implication in some steps in this work. The authors thank the R\&D programs supported both by FUI funds (2008-2011) from the French Ministry of Industry, (DGCIS) and Provence - Alpes - Côte d'Azur Region, SICMED program (INSU, 2011-2014) and Climate KIC (Knowledge Innovation Community) of the European Institute of Innovation \& Technology (EIT) through pathfinders PRECOS (2013-2014) and PRECOS Business (2015). The authors thank W. de Lange, associated editor, and the anonymous reviewers, who contributed by their suggestions to improve the quality of the paper.

\section{References}

Allen R.G., Pereira L.S., Raes D. (1998) Crop evapotranspiration - Guidelines for computing crop water requirements - Irrigation and Drainage paper 56, FAO, Rome, 15 pp.

Astuce \& Tic (2011) Anticipation de l'Aménagement Sécurisé des Territoires Urbanisés, des Campagnes et leur Environnement par les Technologies de l'Information et de la Communication. De Mordant de Massiac J.C., Trolard F. and Bourrié G. coord., Rapport final du programme FUI (2008-2011).

Ayres, R.U. (1995) Life cycle analysis: A critique. Resources, Conservation and Recycling, 14, 199-223.

Ayres, R.U., Ayres, L.W., Martinàs, K. (1998) Exergy, waste accounting and life-cycle analysis, Energy, 23, 5, 355-363.

Baillieux A., Olioso, A., Trolard, F., Chanzy, A., Lecerf, R., Lecharpentier P., Banton ,O., Ruget, F., Ruy, S. (2015) Changements globaux : quels impacts sur l'aquifère de la Crau ? Géologues, 187, 85-92. 
Balestrat, M., Barbe, E., Chery, J.P., Lagacherie, P., Tonneau J.P. (2011) Reconnaissance du patrimoine agronomique des sols : une démarche novatrice en Languedoc-Roussilllon, Norois, 221(4), 83-96.

Bell, S., Morse, S. (2004) Experiences with sustainability indicators and stakeholder participation: a case study relating to a "Blue Plan" project in Malta. Sustainable Development, 12, 1, 1-14.

Biasoli, M., Barberis, R., Ajmone Marsan F. (2006) The influence of a large city on some soil properties and metals content? The Sci. of Total Envir., 356,154-164.

Bonfillon, M.S. (2008) Les cultures irriguées dans l'espace géographique du Canal de Craponne: la question des méthodes de travail. In: Plantes exploitées, plantes cultivées, cultures, techniques et discours. G. Gomet coord., Presse Universitaire de Provence, Marseille.

Bouman, B., Jansen, H., Schipper, R., Nieuwenhuyse, A., Hengsdijk, Bouma, J. (1999) A framework for integrated biophysical and economic land use analysis at different scales. Agriculture, Ecosystems \& Environment, 75 (1-2), 55-73.

Bourrié G., Trolard F., Chanzy A., Ruget F., Lecerf R., Charron F. (2012) Sustainable intensive agriculture: evidence from aqueous geochemistry. Procedia Earth \& Planetary Sci., 7, 93-96.

Brisson, N. (2008) Modéliser la réponse des cultures à la contrainte hydrique avec le modèle STICS pour comparer des stratégies et anticiper les changements climatiques. Innovations agronomiques, 2, 9-18.

Brisson, N., Gary, C., Juste, E., Roche, R., Mary, B., Ripoche, D., Zimmer, D., Sierra, J., Bertuzzi, P., Burger, P., Bussière, F., Cabidoche, Y.M., Cellier, P., Debaeke, P., Gaudilière, J.P., Maraux, F., Seguin, B., Sinoquet, H. (2003) An overview of the crop model STICS. European Journal of Agronomy, 18, 309-332.

Burrato, P., Vannoli, P., Fracassi, U., Basili, R., \& Valensise, G. (2012). Is blind faulting truly invisible? Tectonic-controlled drainage evolution in the epicentral area of the May 2012, Emilia-Romagna earthquake sequence (northern Italy). Annals of Geophysics, 55(4), DOI: 10.4401/ag-6182.

Ceccarelli, T., Bajocco, S., Luigi Perini, L., \& Luca Salvati, L. (2014). Urbanisation and land take of high quality agricultural soils-exploring long-term land use changes and land capability in Northern Italy. International Journal of Environmental Research, 8(1), 181-192.

Chakir R., Madignier A.C. (2006) Analyse des changements d'occupation des sols en France entre 1992 et 2003. Economie rurale, 296 pp.

Chen S., Chen B. (2012) Network environ perspective for urban metabolism and carbon emissions: a case study of Vienna, Austria, Environmental Science and Technology, 46, 4498-4506.

Chen S., Chen B., Fath B.D. (2015) Assessing the cumulative environmental impact of hydropower construction on river systems based on energy network model, Renewable and sustainable Energy Reviews, 42, 78-92. 
Crescenzi, R., Rodriguez-Pose, A., Stoper, M. (2007) The territorial dynamics of innovation: a Europe - United States comparative analysis, Journal of Economic Geography, 7, 6, 673709.

Davodi, S. (2012) Climate risk and security: new meanings of "the environment" in the English Planning System. European planning studies, 20, 1, 49-69.

Day,G.S. (1981) The product life cycle: analysis and application issues, Journal of Marketing, $45,4,60-67$.

DIDD (2010) Stratégie nationale de développement durable pour 2010-2013: vers une économie verte et équitable, Délégation Interministérielle au Développement Durable, report, Paris.

Club Sahel and OECD (2001) Managing the economy locally in Africa. Assessing local economics and their prospects, vol. 1, Summary. Programme municipal, ECOLOC handbook, SAH/D, 511, Paris.

FAO (2009) The state of food insecurity in the World, Report, Roma (Italy).

García, M. (2010). The breakdown of the Spanish urban growth model: Social and territorial effects of the global crisis. International Journal of Urban and Regional Research, 34(4), 967-980.

Geniaux G. (2011) URBANSIMUL: un modèle prototype de simulation de l'occupation du sol à l'échelle parcellaire. http://www.agris.fao.org

Glaeser, E. (2011) Engines of innovation. In: A brighter future with cities, Scientific Amer. J., 36-41.

Graymore, M., Sipe, N., Rickson, R. (2008) Regional sustainability: how useful are current tools of sustainability assessment at the regional scale? Ecological Economics, 67, 3, 362372.

IEA (2008) Perspectives des technologies de l'énergie. Au service du plan d'action du G8 - Scénarios et stratégies à l'horizon 2050. Report, Paris, 13pp.

INSPIRE (2007) Directive 2007/2/CE, JOCE, April 25 th $^{\text {th }}$ 2007. http://www.developpementdurable.gouv.fr/La-directive-europeenne-Inspire-de.html

Buis S, Wallach D, Guillaume S, Varella H, Lecharpentier P, Launay M, Guerif M, Bergez JE, Justes E. (2011) The STICS crop model and associated software for analysis, parameterisation and evaluation. In: Ma, L (ed), Methods of Introducing System Models into Agricultural Research, Advances in Agricultural Systems Modeling 2, American Society of Agronomy, Crop Science Society of America, and Soil Science Society of America, Madison, p 395-426.

Lagacherie, P. and Ménard, T. (2007) Un indice de qualité des sols, work document, Inra, UMR Lisah, Montpellier.

Luis, M. D., Raventós, J., González-Hidalgo, J. C., Sánchez, J. R., \& Cortina, J. (2000). Spatial analysis of rainfall trends in the region of Valencia (East Spain). International Journal of Climatology, 20(12), 1451-1469.

Mallet J.L. (2002) Geomodeling, Oxford University Press.

Malucelli, F., Certinin, G., Scalenghe, R. (2014) Soil is brown gold in Emilia-Romagna Region, Italy, Land Use Policy, dx.doi.org/10.1016/j.landusepol.2014.01.019 
OECD (2003) OECD environmental indicators - development, measurement and use Reference paper, 37 pp., http://www.oecd.org/env/

Olioso A., Lecerf R., Chanzy A., Ruget F., Huard F., Baillieux A., Rossello P., Lecharpentier P., Trolard F., Charron F., Ruy S., Alkacem Alosman M., Cognard-Planck A.L., Seguin B., Courauldt D., Gallego-Elvira B., Garrigues S. (2013a) Bilan hydrique des agrosystèmes de Crau face aux changements globaux. In: Ecologie et conservation d'une steppe méditerranéenne - La plaine de Crau, Tatin L., Wolff A., Boutin J., Colliot E. and Dutoit T. coord., Editions QUAE, Paris.

Olioso A., Lecerf R., Baillieux A., Chanzy A., Ruget F., Banton O., Le Chapentier P., Trolard F., Cognard-Plancq A.L. (2013b) Modelling of drainage and hay production over the Crau aquifer for analysing impact of global change on aquifer recharge. Procedia, Environ. Sci., 19, 691-700.

Pachauri, D.L. and Reisinger, A.(eds) (2007) Climate change: synthesis report, IPCC, Genève.

Pageaud, D. and Carré, C. (2009) La France vue par CORINE Land Cover, outil européen de suivi de l'occupation des sols. In: Le point sur... Commissariat Général au Développement Durable, 10,1-4.

Parkhurst, D.L. and Appelo, C.A.J. ((1999) User's guide to PHREEQC (version 2): A computer program for speciation, batch-reaction, one-dimensional transport, and inverse geochemical calculations. Water-Resources Investigations Report 99-4259, U.S. Geological Survey.

Rico-Amoros, A. M., Olcina-Cantos, J., \& Sauri, D. (2009). Tourist land use patterns and water demand: evidence from the Western Mediterranean. Land Use Policy, 26(2), 493-501.

Ruellan A. (2010) Des sols et des hommes, un lien menacé, IRD Edition, Marseille.

Sapoval Y.L. (2011) Comment faire émerger une offre urbaine durable? In: Atlas du développement durable et responsable, G. Pennequi and A.T. Mocilnikar coord., 290294.

Salvati, L. (2014). The spatial pattern of soil sealing along the urban-rural gradient in a Mediterranean region. Journal of Environmental Planning and Management, 57(6), 848-861.

Schmitt, P. (2010) Intra-metropolitan polycentricity in practice-reflections - Challenges and conclusions from 12 European metropolitan areas. Final report of the METREXExpert Group on Intra-Metropolitan Polycentricity. Retrieved, November, vol. 28.

Trolard F. and Astuce \& Tic's consortium (2010) Etalement urbain et changements globaux : l'urgence de considérer les sols et l'eau dans un modèle intégratif. Energie Liaison Francophonie, 86, 147-153.

Trolard F. and Dangeard M.L. (2014) Les sols, l'eau et la production agricole : des ressources de base face à l'étalement urbain et aux changements climatiques. In: Penser une démocratie alimentaire - Thinking a food democracy, Lascaux proposals between natural resources and food needs, Colard Dutilleul F. and Bréger F. coord., INIDA ed., San José, Costa Tica, 113-124. 
Trolard F., Dangeard M.L., de Mordant de Massiac J.C., Bourrié G., Lecerf R., Le Pors B., Chanzy A., Dangeard A., Keller C., Charron F. and the consortium Astuce \& Tic (2013a) La disparition des habitats naturels et agricoles vue par le programme Astuce \& Tic. In: Ecologie et conservation d'une steppe méditerranéenne - La plaine de Crau, Tatin L., Wolff A., Boutin J., Colliot E. and Dutoit T. coord., Editions QUAE, Paris.

Trolard F., Reynders S., Dangeard M.L., Bourrié G., Descamps, B., Keller, C., de Mordand de Massiac, J.C. (2013b) Territoire, ville et champagne face à l'étalement urbain et aux changements climatiques. Une démarche intégrative pour préserver les sols, l'eau et la production agricole. Edition Johanet, Paris, $152 \mathrm{pp}$.

Ungaro, F., Calzolari, C., Pistocchi, A., \& Malucelli, F. (2014). Modelling the impact of increasing soil sealing on runoff coefficients at regional scale: a hydropedological approach. Journal of Hydrology and Hydromechanics, 62(1), 33-42.

Vicente Serrano, S. M., González-Hidalgo, J. C., Luis, M. D., and Raventós, J. (2004). Drought patterns in the Mediterranean area: the Valencia region (eastern Spain). Climate Research, 26, 5-15.

Vohland K. and Barry B. (2009) A review of in situ rainwater harvesting (RWH) practices modifying landscape functions in African drylands. Agriculture, Ecosystems \& Environment, 131, 119-127.

Von Bahr, B. and Steen, B. (2004) Reducing epistemological uncertainty in life cycle inventory, Journal of cleaner Production, 12, 4, 369-388.

Waddel, P. (2002) UrbanSim: modelling urban development for land use, transportation and environmental planning, Journal of the American Planning Association, 68, 3, 297-314.

White, R., Engelen, G. (1993) Cellular automata and fractal urban form: a cellular modelling approach to the evolution of urban land use patterns. Environment and Planning A, 25(8), 1175-1199.

White, R., Engelen, G., Uljee, I. (1997) The use of constrained cellular automata for highresolution modeling of urban land-use dynamics. Environment and Planning B: Planning and Design, 24(3), 323-343.

Wolff A., Tatin L. and Dutoit T. (2013) La Crau, une steppe méditerranéenne unique en France. In: Ecologie et conservation d'une steppe méditerranéenne - La plaine de Crau, Tatin L., Wolff A., Boutin J., Colliot E. and Dutoit T. coord., Editions QUAE, Paris.

World Bank (2007) Strategy of WB on the environment, Report 2007.

World Bank (2009) Development in the world, Report 2009.

Xia Li and Gar-On Yeh A. (2000) Modeling sustainable urban development by the integration of constrained cellular automata and GIS, Journal of the American Planning Association, $14,2,131-152$.

Zhang, X., Chen, J., Tan, M., Sun, Y. (2007) Assessing the impact of urban sprawl on soil resources of Nanjing city using satellite images and digital soil databases. Catena, 69, 1630 . 